\title{
Distribution of Heavy Metals in the Liver of Foetuses and Female Mice after Oral Administration during Pregnancy - a Histochemical Study
}

\author{
Lenka Krejčířová1, Irena Lauschová ${ }^{1}$, Petr Č́ížek ${ }^{2}$ \\ ${ }^{1}$ Department of Histology and Embryology, Faculty of Medicine, Masaryk University, Brno, Czech Republic \\ ${ }^{2}$ Department of Anatomy, Histology and Embryology, Faculty of Veterinary Medicine, University of Veterinary \\ and Pharmaceutical Sciences Brno, Czech Republic
}

Received May 29, 2009

Accepted January 19, 2010

\begin{abstract}
The aim of this work was to study the distribution of heavy metals and of subsequently developed morphological changes in the liver of female mice and their foetuses after oral administration of high doses of lead, mercury, and cadmium ( $0.03 \mathrm{mg}$ of metal per mouse and day).

Heavy metals were administered to pregnant female mice on days 9-20 of pregnancy. The animals were euthanised by cervical dislocation. Samples of mother and foetal liver were subsequently collected and processed by means of the common technique for light and electron microscopy. Histochemical reaction based on metal conversion into appropriate sulphide that conjugates with silver was used for detection of heavy metals.

Deposits of heavy metals were found at the periphery of lobules of the central vein in the liver of female mice. On the contrary, in the liver of foetuses no predilection site for localisation of the reaction product could be identified. At the electron microscopy level, accumulation of heavy metals was connected as a rule with the occurrence of certain damage to some organelles. Deposits of the reaction product were located mainly in hepatocytes and Kupffer cells. Heavy metals were bound to the heterochromatin of cell nuclei, as well as to some cytoplasmic organelles, such as rough endoplasmic reticulum, mitochondria, ribosomes, and lysosomes. The presence of heavy metals was associated with obliteration of cisternae of the rough endoplasmic reticulum, separation of ribosomes, and destruction of lysosomes. Vacuolation of cell cytoplasm was also a frequent phenomenon. An interesting finding was the "contrasting" of structures containing nucleic acids.

Accumulation of metals in the liver of pregnant mice and their foetuses observed in our study indicated that placental barrier does not protect the foetal organism against penetration of metals. Their higher accumulation in foetal compared to maternal liver can be explained by the intense metabolism of differentiating hepatocytes.
\end{abstract}

Cadmium, mercury, lead, histochemical detection, light and electron microscopy, liver, mouse

Many morphological and histochemical studies are concerned with the detection of heavy metals in mammalian liver, at the level of both light and electron microscopy (Bucio et al. 1995; Buchman et al. 2001; Gabis et al. 1996; Lichtlen et al. 2001; Mullins et al. 1998; Wang et al. 2004). Accumulation of heavy metals in parenchymatous organs of animals living in contaminated environment was described in detail in the literature. These studies reveal that heavy metals mainly accumulate in the liver (Plaa and Hewitt 1998; Garipay et al. 2003; Pereira et al. 2006; Stoltenberg et al. 2003; Sween 2007).

Experimental studies of accumulation and distribution of heavy metals after administration of a known dose in the course of a certain time were carried out in farm animals (Hamilton et al. 1982; Hansen et al. 1976; Horky et al. 2002; Kreeger et al. 1991). Heavy metals were given to experimental animals orally, intravenously, and by other routes (percutaneous, as inhalants).

To our knowledge, data on administration of heavy metals in animals during pregnancy have been missing in the scientific literature. Therefore this work focuses on histochemical detection of heavy metals in the foetal and maternal mouse liver. Heavy metals were monitored during the pregnancy period, when they were transported from the maternal

Address for correspondence:

MUDr. L. Krejčírová

Department of Histology and Embryology

Faculty of Medicine, Masaryk University

Kamenice 3, CZ-625 00 Brno

Czech Republic

Phone: +420 549495401

Fax: +420 549491320

E-mail: lkrejcir@med.muni.cz

http://www.vfu.cz/acta-vet/actavet.htm 
organism through the placenta to foetuses. The aim of this study was to compare accumulation and localisation of heavy metals in the liver of mothers and their foetuses, and to establish the potential range of liver damage at the level of both light and electron microscopy.

\section{Materials and Methods}

Forty pregnant random bred albino mice (aged 3 months) were divided into four groups of 10 animals each. The females in Groups 1-3 received water with dissolved salts of metals during days 9-20 of their pregnancy. Group 4 served as control and the animals received only water (without metal). Group 1 received water with cadmium sulphate p.a. (Merci), at the concentration of $0.015 \mathrm{~g} / \mathrm{l}$, at doses of $0.03 \mathrm{mg} / \mathrm{mouse} /$ day; Group 2 received lead as lead nitrate p.a. (Merci), at the concentration of $0.015 \mathrm{~g} / 1$ at doses of $0.03 \mathrm{mg} / \mathrm{mouse} /$ day; and Group 3 received mercury in the form of mercuric chloride p.a. (Merci), at the concentration of $0.015 \mathrm{~g} / 1$ at doses of $0.03 \mathrm{mg} /$ mouse/day.

Final doses of heavy metals were determined according to a study of the influence of heavy metals on the liver of calves, published by Horky et al. (2002). The approximate water quantity that is required for one experimental group of ten pregnant females during one day was determined before the experiment. The appropriate quantity of metal salts that must be dissolved in water was also calculated to provide each experimental animal with the necessary dose of heavy metal per day. Pregnant females on day 20 of their pregnancy were euthanised by cervical dislocation. From each experimental female, samples of liver were collected and prepared for light and electron microscopy. Whole foetuses from the right uterine horn were processed for light microscopy, and only liver of foetuses from the left uterine horn were used for electron microscopy.

Heavy metals were detected by light and electron microscopy. According to Pearse (1972) it was used for histochemical detection of $\mathrm{Cd}, \mathrm{Hg}$, and $\mathrm{Pb}$.

\section{Light microscopy}

Samples of liver from pregnant females and foetuses were fixed for one day in $4 \%$ formaldehyde saturated for 5 min with gaseous hydrogen sulphide and subsequently rinsed in a mixture of $300 \mathrm{mmol} / \mathrm{l}$ solution of sucrose with sodium azide for $2 \times 24 \mathrm{~h}(50 \mathrm{~g}$ sucrose and $500 \mathrm{ml}$ water, and $325 \mathrm{mg}$ sodium azide). The samples were embedded in paraffin and 4-5 $\mu$ m thick sections were cut. Deparaffinised sections were subsequently exposed to a mixture of 5 parts of $20 \%$ arabic gum, 1 part of a mixture of $2 \%$ solution hydroquinone with $5 \%$ citric acid juxta ratam 1:3, and 0.1 part of $10 \%$ silver nitrate (Table 1 ) in darkness.

Table 1. Preparation of the mixture for exposure of sections

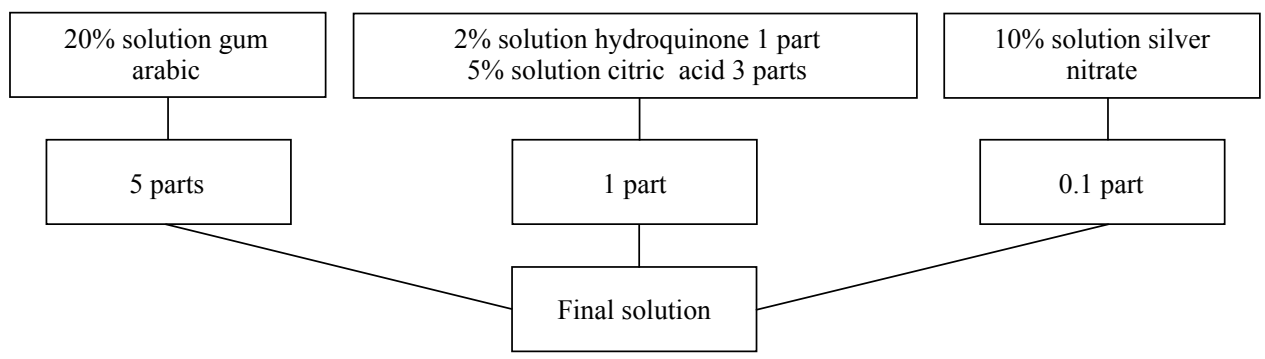

Deposits of the reaction product were black-brown stained. For easier orientation, histological sections were stained with haematoxylin-eosin.

\section{Electron microscopy}

Samples of liver from pregnant mice and their foetuses were fixed with $300 \mathrm{mmol} / 1$ glutaraldehyde in 100 mmol/l cacodylate buffer at pH 7.36 saturated with gaseous hydrogen sulphide for $2 \mathrm{~h}$. Postfixation was done again with $300 \mathrm{mmol} / 1$ glutaraldehyde in $100 \mathrm{mmol} / 1$ cacodylate buffer at $\mathrm{pH} 7.36$ without hydrogen sulphide for $2 \mathrm{~h}$. The samples were washed in $300 \mathrm{mmol} / \mathrm{l}$ sucrose in an open vessel for $3 \times 2 \mathrm{~h}$. Thereafter they were placed into a saturated solution of CuSO4 for $18 \mathrm{~h}$ and washed in $300 \mathrm{mmol} / 1$ sucrose for $30 \mathrm{~min}$. Embedding in Durcupan ACM was done in a standard manner. Sections $(50 \mathrm{~nm})$ were made by an LKB $8802 \mathrm{~A}$ ultramicrotome and exposed in the same way as for light microscopy. Non-contrasted exposed sections were examined and photographed with an FEI Morgagni 286 D electron microscope.

The experiments on laboratory mice were carried out with the agreement of Ethics Committee, on $25^{\text {th }}$ of May 2004, under the Act No. 311/1997 of Coll. of Laws (supplement). 


\section{Results}

Light microscopy

The result of the histochemical procedure is the reaction product represented by sulphide metals. After physical exposure of the above mentioned mixture (Table 1) it looks like relatively coarse brown-black eumelanin granules. These granules of the reaction product were found only in fetal liver and in the liver of females in Groups 1-3 drinking water with lead, mercury and/or cadmium. Negative reaction was found in control animals. The density of the reaction product was significantly higher in the liver of foetuses than in maternal liver in Groups 1-3.

In the liver of pregnant females, deposits of the reaction product occurred predominantly in the peripheral (periportal) zone of the liver lobule (Plate V, Fig. 1). Sporadically deposits were seen in other areas of the liver lobule. The reaction product was present only in hepatocytes. The other cell types showed negative reaction distinguished under light microscopy. Accumulation of heavy metals was not associated with degenerative changes.

In the foetal livers, the granules of the reaction product were more abundant and distributed equally in the parenchyma (Plate V, Fig. 2). Accumulation was found in the hepatocytes of hepatic trabeculae, as well as in the endothelium of sinusoids. Contrary to mothers, granules of the reaction product were often seen in erythrocytes. No degenerative changes were found in the hepatic parenchyma of the foetuses, either.

\section{Electron microscopy}

The resulting product of the histochemical reaction appears after physical exposition as electron-dense granules, $0.02-0.04 \mu \mathrm{m}$ sized.

The ultrastructural findings in animals given cadmium, mercury or lead were analogous. The reaction product was found especially in the cell nuclei of hepatocytes, usually connected with heterochromatin (Plate VI, Fig. 3).

The reaction product was occasionally also seen in the nucleoli of hepatocytes (Plate VI, Fig. 4). Various size deposits of the reaction product were found in lysosomes, namely those in Kupffer cells (Plate VII, Fig. 5). Solitary granules of the reaction product were recorded in the mitochondria of the hepatocytes. Electron microscopy revealed wellpronounced changes. Occasionally defects of the nuclear envelope were observed in nuclei. Ultrastructural alterations of the rough endoplasmic reticulum were sometimes found in the cytoplasm areas of cells. These alterations consisted of obliteration of cisternae and separation of ribosomes. Disintegrated lysosomes represented a relatively frequent finding. Small vacuoles occurred occasionally in hepatocytes (Plate VII, Fig. 6). All degenerative changes were more expressed in foetuses than in their mothers.

The usual side effect of heavy metal detection was represented by intensive staining (contrast) of structures containing nucleic acids or nucleoproteins, such as heterochromatin, nucleolus, and ribosomes.

\section{Discussion}

Our study has shown that the supply of all three heavy metals at high doses causes their accumulation in the liver of females and their foetuses. The fact that the extent of accumulation was higher in foetal livers is remarkable.

It was found that the distribution of the reaction product, and/or of the metals under study, differed in the maternal and foetal livers. Deposits of heavy metals were found at the periphery of liver lobules in females. It could be related to the findings of Jungermann et al. (1996) that the hepatocytes in the proximity of arterioles are the first in contact with the incoming blood (as opposed to the hepatocytes in the centre), and hence they are the 
first to absorb toxins. We also assume that the cumulation of heavy metals depends on the lobule vascularisation.

Contrary to our findings, Horky et al. (2002) described deposits of metals in the central zone of liver lobules. A possible explanation of this difference may be the fact that Horky et al. (2002) used single metals whereas in our experiment a combination of metals was used. This could cause toxic effect of heavy metals on the hepatic parenchyma. The toxic effect can also be caused by a longer period of administration leading to chronic intoxication of the organism, and not to acute intoxication as in our case. This result is in accordance with Jungermann et al. (1996).

In the liver of foetuses, contrary to females, no predilection sites of localisation of the reaction product were identified. This is not a surprising finding, because typical hepatic lobules differentiate as late as at ca postnatal day 10 (Dvořák 1961). At this time (prenatal), the hepatocytes are not arranged into long radial continuous trabeculae, but are organised rather into smaller groups or short trabeculae. The fact that foetal liver accumulated heavy metals not only in the hepatocytes, but also in the endothelium of the sinusoids, has been noted.

A different accumulation ability of heavy metals was observed in the erythrocytes present in the mother and foetal liver. Accumulation of metals was only seen in foetal erythrocytes. This finding corresponds with the results of Nelson (1971) and Suzuki et al. (1967, 1971) about mercury transport through the mouse placenta. The authors found that foetal erythrocytes accumulate metals by about $30 \%$ more than those of their mothers.

At the level of electron microscopy, accumulation of heavy metals was connected as a rule with the occurrence of certain damage to some structures. The reaction product was usually detected in the nucleus (sometimes in the nucleolus), namely in heterochromatin and in some cytoplasmic organelles: most often in lysosomes, further in the rough endoplasmic reticulum, ribosomes, and mitochondria.

The bond between heavy metals and chromatin was also documented biochemically by Morselt et al. (1983) and Michailova et al. (1997). This coupling causes condensation of nuclear chromatin. According to some scientists it is the first symptom of cell intoxication and is irreversible. Condensation of chromatin is followed by accumulation of perichromatin granules. Even if quantitative evaluation of perichromatin granules was not done in our study, they occurred in hepatocytes in our materials. Defects of the nuclear envelope were sometimes also found. Larger defects were described by Kusell et al. (1978), Walton and Buckley (1977), and Dubreuil et al. (1979). These defects resulted even in the effusion of the nuclear content into the cytoplasm and cell death. A similar toxic effect of heavy metals on nucleolar RNA was described by Puvion and Lange (1980). The binding between the reaction product and nucleolar RNA was seen only rarely in our material.

Heavy metals were frequently accumulated in lysosomes, namely in Kupffer cells. This finding was not surprising. The ability of lysosomes to absorb, eliminate, separate or mobilise heavy metals was reported by Sternlieb and Goldfischer as early as in 1976. The reaction product was also detected in the rough endoplasmic reticulum. Morphological alterations caused by heavy metals consist in obliteration of cisternae and separation of ribosomes. In contradiction to Desnoyers and Chang (1975) or Trump and Ericsson (1965), obliteration and fragmentation of rough endoplasmic reticulum cisternae were observed sporadically in our study. Our findings thus indicate that heavy metals may significantly affect proteosynthesis.

Granules of the reaction product were also detected in mitochondria. Localisation of heavy metals in these organelles can affect oxidative phosphorylation. "Ischaemic" changes as the result of damage to mitochondria were described by Trump et al. (1966).

Severe changes and damage of cells were sometimes found. Defects of the nuclear 
envelope, vacuoles in the cytoplasm, enlarged mitochondria showing internal disintegration, and considerable clearing of the matrix were observed in our material.

According to our study, the fact that heavy metals were detected in both maternal and foetal liver demonstrates that the placenta does not protect the foetus against the transfer of these metals from the mother's organism. Transfer of lead, mercury, and cadmium was also mentioned by Rabinowitz and Finch (1984), Suzuki et al. (1967, 1971), Berlin and Ullberg (1983), and Miller et al. (1982). Accumulation of heavy metals in the organs of the foetus was described by Wang et al. (2004).

Theoretically, it is possible to hypothetise that heavy metals distinctly accumulate in the foetal liver because the cells of embryonic tissues show considerable metabolic activity. This, together with the immature immune system, gives a chance to heavy metals to involve in biological processes at molecular level (Jacquet et al. 1977; Sajiki and Fukushima 1984; Johnson and Walker 1970; Müller and Stacey 1989). Our results and hypothesis are in accordance with the results of many biochemists.

\section{Distribuce těžkých kovů v játrech fetů a myších samic po perorálním podávání během březosti - histochemická studie}

V práci byla studována distribuce těžkých kovů a jimi vyvolaných morfologických změn $\mathrm{v}$ játrech březích myších samic a myších fetů po perorální aplikaci vysokých dávek olova, rtuti a kadmia (0,03 mg kovu na myš a den).

Těžké kovy byly podávány březím myším samicím 9. - 20. den březosti, kdy byla zvířata usmrcena cervikální dislokací. Následně byly odebrány vzorky jater matek a fetů a zpracovány klasicky pro účely světelné a elektronové mikroskopie. K detekci těžkých kovů byla použita histochemická reakce, která spočívá v konverzi kovu v příslušný sulfid, který se konjuguje se stř́ibrem.

Na základě našich výsledků lze konstatovat, že těžké kovy pronikají placentou a kumulují se více $\mathrm{v}$ játrech plodu než $\mathrm{v}$ játrech matky. Depozita těžkých kovů byla $\mathrm{v}$ játrech samic vázána na periferii jaterních lalůčků. Naopak v játrech fetů jsme nezjistili predilekční místa lokalizace reakčního produktu. Na úrovni elektronové mikroskopie byla kumulace těžkých kovů zpravidla spojena s výskytem poškození některých organel. Depozita reakčního produktu byla lokalizována především v hepatocytech a Kupfferových buňkách. V buněčných jádrech se těžké kovy vázaly na heterochromatin, u cytoplazmatických organel na drsné endoplazmatické retikulum, mitochondrie, ribozomy a lyzozomy. Př́tomnost těžkých kovů byla spojena s obliterací cisteren drsného endoplazmatického retikula, odlučováním ribozomů a destrukcí lyzozomů. Častým jevem byla i vakuolizace buněk. Zajímavým nálezem bylo „kontrastování“ struktur, které jsou tvořeny nukleovými kyselinami.

\section{Acknowledgement}

We wish to thank Assoc. Prof. MUDr. Jitka Št'astná, CSc., for the many fruitful discussions on heavy metals, which helped us considerably in preparing this manuscript, and Ms. D. Hradilová, Ms. R. Šebestová and Mr. L. Ilkovics for their excellent technical assistance.

\section{References}

Berlin M, Ullberg S 1963: Accumulation and retention of mercury in the mouse. Arch Environ Health 6: 583-616

Bucio L, Souza V, Albores A, Sierra A, Chavez E, Carabez A, Gutierrez-Ruiz MC 1995: Cadmium and mercury toxicity in a human fetal hepatic cell line (WRL 68 cells). Toxicology 102: 285-299

Buchman AL, Neely M, Grossie VB Jr, Truong L, Lykissa E, Ahn C 2001: Organ heavy-metal accumulation during parenteral nutrition is associated with pathologic abnormalities in rats. Nutrition 17: 600-606

Desnoyers PA, Chang LW 1975: Ultrastructural changes of the liver after chronic exposure to methylmercury. Environ Res 10: 59-75

Dubreuil A, Hollande E, Bovley G, Bovdewe C 1979: Effects of lead microparticles on the growth characteristics of the BMK 21 fibroblast cell line. Toxicology 13: 249-262 
Dvořák, M 1961: Morfogenesa a histogenesa jater laboratorní krysy (Rattus norvegicus Erx.) [The morphogenesis and histogenesis of the liver of the laboratory rat (Rattus norvegicus Erx.)]. Kandidátská práce - lékařská fakulta UJEP - Brno [Dissertation, Fac. of Medicine, UJEP University, Brno]

Gabis KK, Gildemeister OS, Pepe JA, Lambrecht RW, Bonkovsky HL 1996: Induction of heme oxygenase-1 in LMH cells. Comparison of LMH cells to primary cultures of chick embryo liver cells. Biochim Biophys Acta 1290: 113-120

Garipay RC, Muro Cacho C, Khlifi A, Hahn G, Stedeford T, Banasik M, Harbison RD 2003: Tissue metal concentrations and histopathology of rats gavaged with vitrified soil obtained from the former Charleston Naval Shipyard (SC, USA). J Hazard Mater 100: 1-12

Hamilton PB, Huff WE, Harris JR, Wyatt RD 1982: Natural occurrences of ochratoxicosis in poultry. Poult Sci 61: 1832-1841

Hansen LG, Dorner JL, Byerly CS, Tarara RP, Hinesly TD 1976: Effects of sewage sludge-fertilized corn fed to growing swine. Am J Vet Res 37: 711-714

Horky D, Illek J, Pechova A 2002a: Histochemical and ultrahistochemical localization of heavy metals in calf organs. Microsc Res Tech 56: 435-450

Jacquet P, Gerber GB, Maes J 1977: Biochemical studies in embryo after exposure of pregnant mice to dietary lead. Bull Environ Contam Toxicol 18: 271-274

Johnson AD, Walker GP 1970: Early actions of cadmium in the rat and domestic fowl testis. J Reprod Fert 23: $463-468$

Jungermann K, Kietzmann T 1996: Zonation of parenchymal and nonparenchymal metabolism in liver. Annu Rev Nutr 16: 179-203

Kreeger JM, Frappier DC, Kendall JD 1991: Systemic glycoproteinosis resembling Lafora's disease in a cow. Cornell Vet 81: 215-221

Kusell M, Lake L, Anderson M, Gerschenson LE 1978: Cellular and molecular toxicology of lead. 2. Effect of lead on d-aminolevulinic acid synthetase of cultured cells. Toxicol Environ Hlth 4: 515-525

Lichtlen P, Wang Y, Belser T, Georgiev O, Certa U, Sack R, Schaffner W 2001: Target gene search for the metal-responsive transcription factor MTF-1. Nucleic Acids Res 29: 1514-1523

Michailova P, Ramella L, Sella G, Bovero S 1997: C band variation in polytene chromosomes of Chironomus riparius (Diptera, Chironomidae) from a polluted Piedmont station (Italy). Cytobio 90: 139-151

Miller Ch, Buck WB, Hembrough FB, Cunningham WL 1982: Fetal rat development as influenced by Materna lead exposure. Veter Human Toxicol 24: 163-66

Morselt AFW, Peereboom-Stegman JHJC, Puvion E 1983: Investigation of the mechanism of cadmium toxicity at cellular level II. Arch Toxicol 52: 99-108

Müller L, Stacey NH 1989: Subclinical response to cadmium in liver cells. Biol Trace Element Res 21: 317-323

Mullins JE, Fuentealba IC 1998: Immunohistochemical detection of metallothionein in liver, duodenum and kidney after dietary copper-overload in rats. Histol Histopathol 13: 627-633

Nelson N 1971: Hazards of mercury. Special report to the secretary's pesticide advisory committee. Environ Res 4: 1-69

Pearse AGE 1972: Histochemistry. Churchill Livingstone, Edinburgh and London. 3rd ed., 1511 p.

Pereira R, Pereira ML, Ribeiro R, Goncalves F 2006: Tissues and hair residues and histopathology in wild rats (Rattus rattus L.) and Algerian mice (Mus spretus Lataste) from an abandoned mine area (Southeast Portugal). Environ Pollut 139: 561-575

Plaa GL, Hewitt WR 1998: Toxicology of the Liver. Taylor Francis, Washington. 2nd ed

Puvion E, Lange M 1980: Functional significance of perichromatin granule accumulation induced by cadmium chloride in isolated rat liver cells. Exp Cell Res 128: 47-58

Rabinowitz M, Finch H 1984: Cadmium content of umbilical cord blood. Environ Res 34: 120-122

Sajiki J, Fukushima E 1984: Change in alkaline phosphatase activity in rats administered by cadmium chloride. Eisei Kagaku 30: 309-312

Sternlieb I, Goldfischer S 1976: Heavy metals and lysosomes. Front Biol 45: 185-200

Stoltenberg M, Locht L, Larsen A, Jensen D, Danscher G 2003: In vivo cellular uptake of bismuth ions from shotgun pellets. Histol Histopathol 18: 781-785

Suzuki T, Matsumoto N, Miyama T, Katsunama H 1967: Placental transfer of mercuric chloride, phenylmercury acetate and methylmercury acetate in mice. Industr Health 5: 149-155

Suzuki T, Miyama T, Katsunuma TH 1971: Comparison of mercury contents in maternal blood, umbilical cord blood and placenta tissue. Bull Environ Contam Toxicol 5: 502-508

Sween M 2007: Pathology of the Liver. Churchill Livingstone Elsevier. 5th ed.

Trump BF, Ericsson JL 1965: Some ultrastructural and biochemical characteristic of cell injury. In: The inflammatory process (Zweifack BW, McCluskey RT, Grant LH, Eds.) New York

Trump BF, Goldblatt PJ, Stowell RC 1966: Studies on necrosis of mouse liver in vitro: ultrastructural alterations in the mitochondria of hepatic parenchymal cells. Lab Invest 14: 343-371

Walton J, Buckley IK 1977: The lead-poisoned cell: a fine structural study using cultured kidney cells. Exp Molec Pathol 27: 167-182 
Wang Y, Wimmer U, Lichtlen P, Inderbitzin D, Stieger B, Meier PJ, Hunziker L, Stallmach T, Forrer R, Rulicke T, Georgiev O, Schaffner W 2004: Metal responsive transcription factor 1 (MTF 1) is essential for embryonic liver development and heavy metal detoxification in the adult liver. FASEB J 18: 1071-1079 
Plate V

Krejčíŕová L. et al.: Distribution ... pp. 225-232

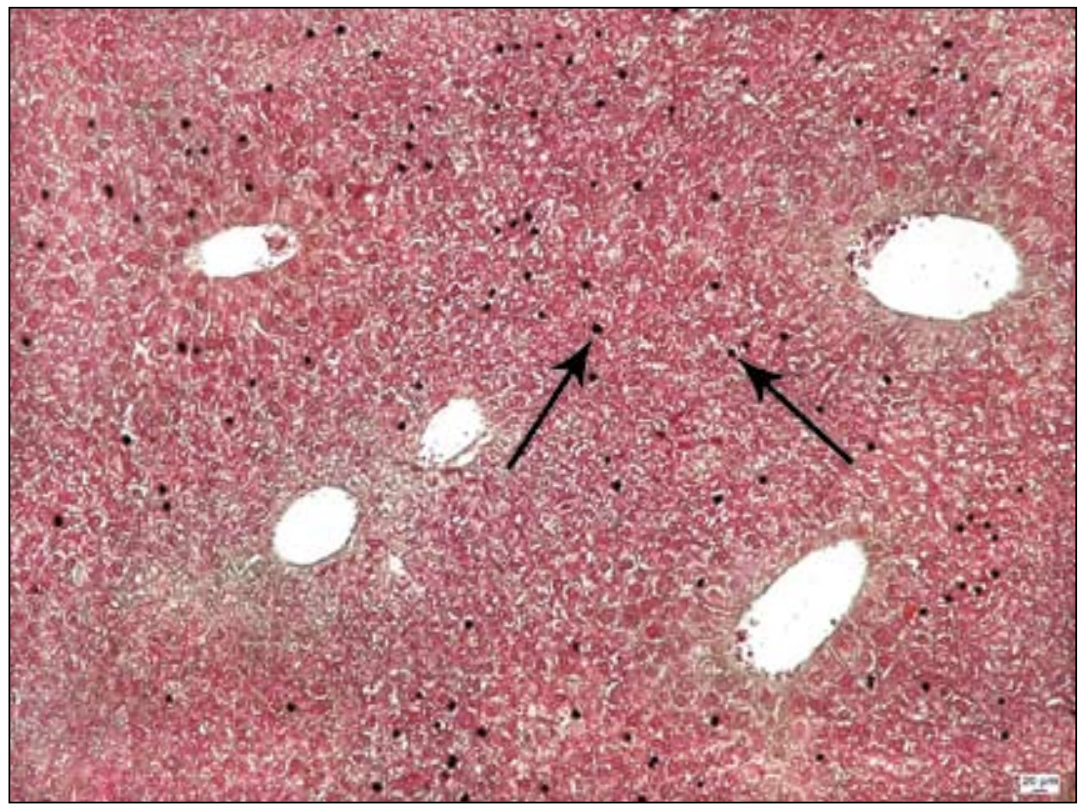

Fig. 1. Part of liver parenchyma with the dark granules of the reaction product $\rightarrow$ located in the periportal zones of lobules of the central vein of pregnant female mice. Magnification $\times 100$

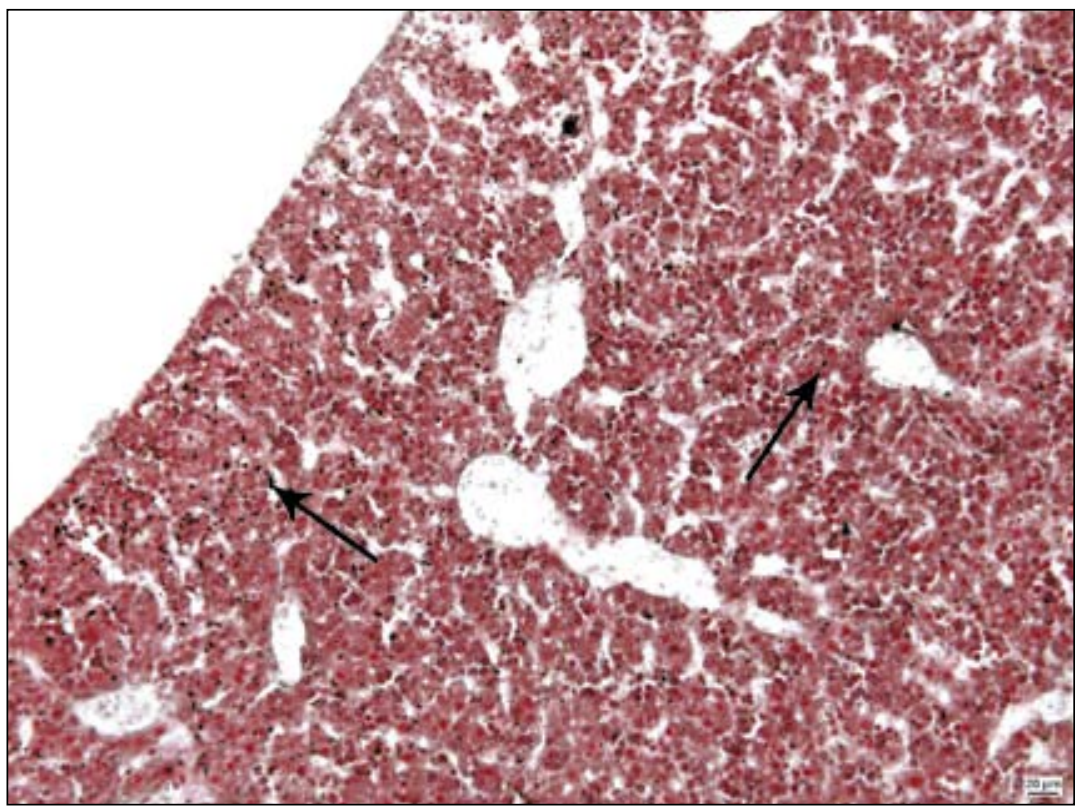

Fig. 2. Dark granules of the reaction product $\rightarrow$ are dispersed in the liver of the foetus. Magnification $\times 150$ 


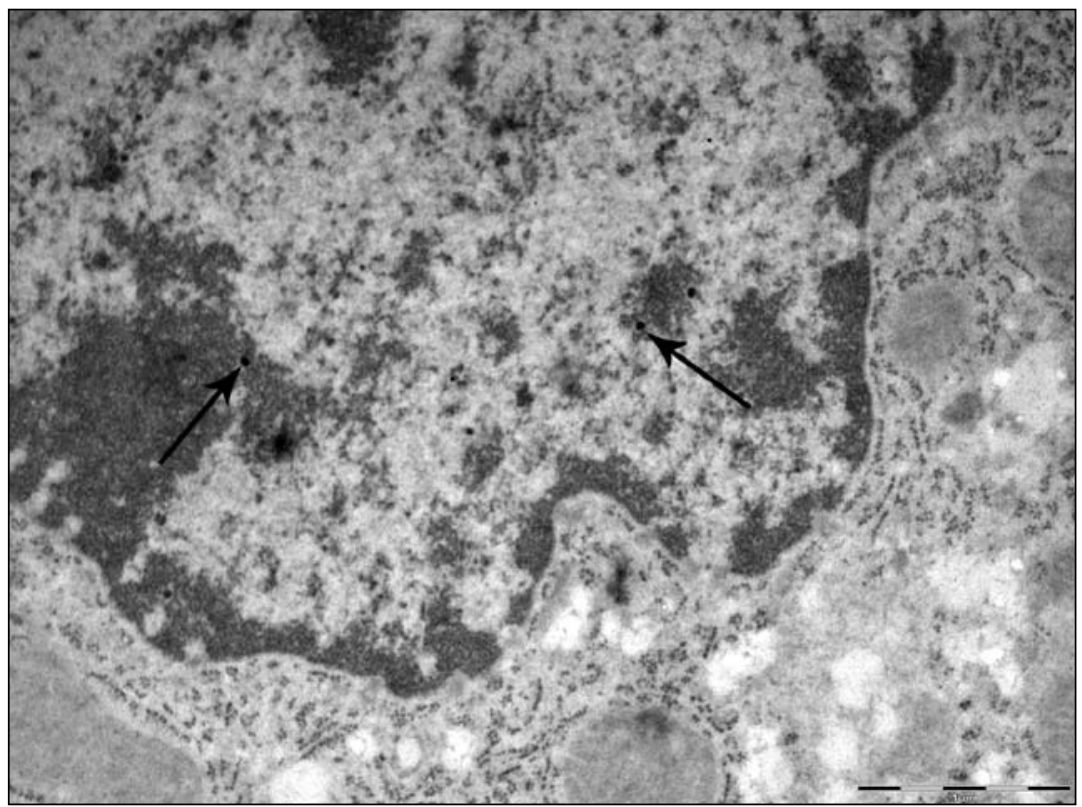

Fig. 3. Electronogram of a hepatocyte. The nucleus with the granules of the reaction product $\rightarrow$ localised on heterochromatin. Magnification $\times 33,000$

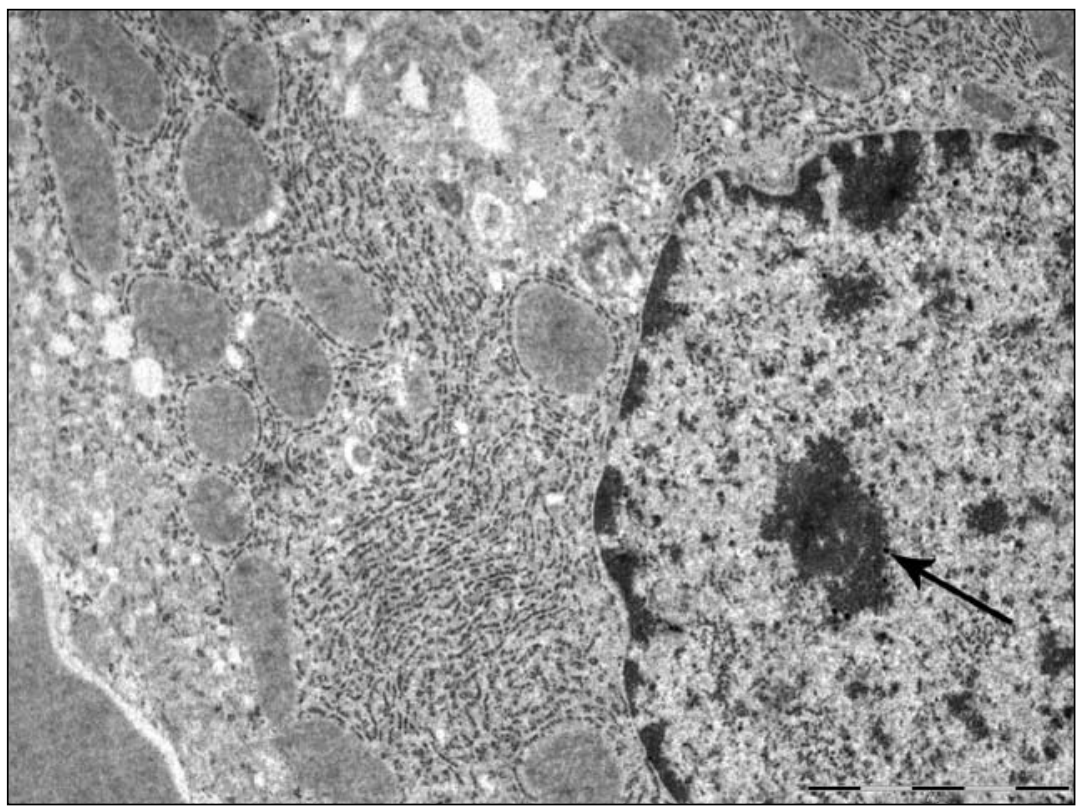

Fig. 4. The electronogram of hepatocyte. Granules of the reaction product $\rightarrow$ localised on nucleolus and cytoplasmatic organelles. Magnification $\times 20,000$ 


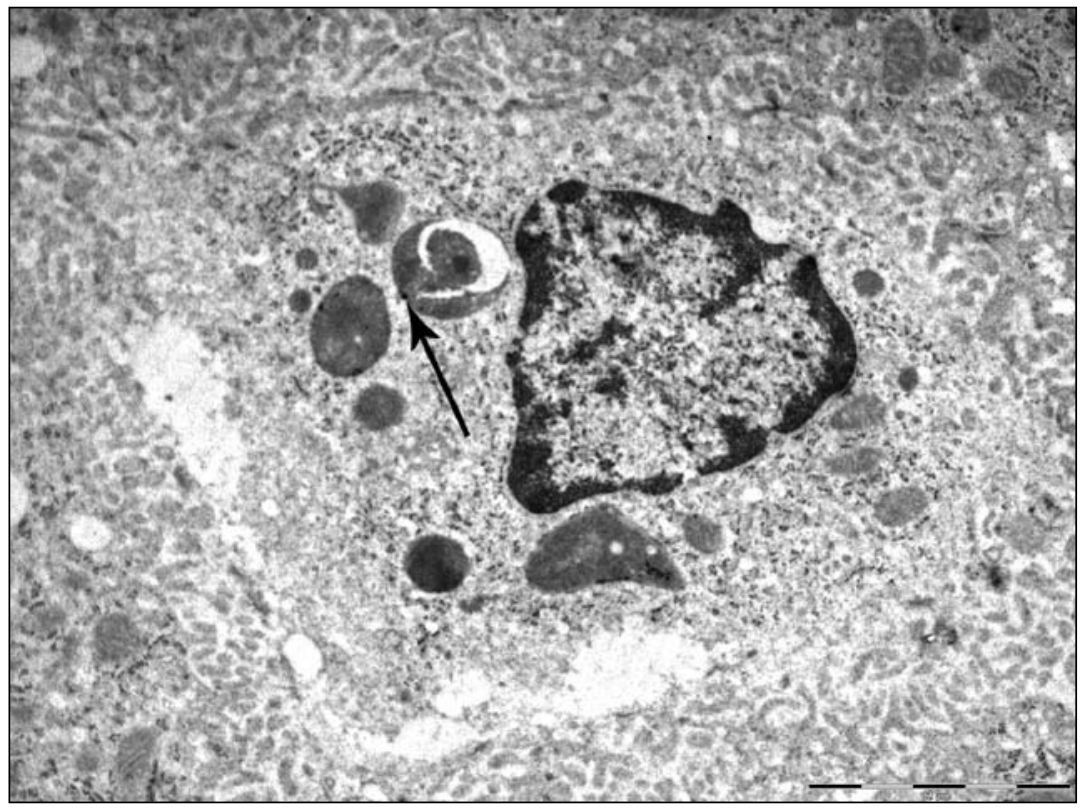

Fig. 5. A Kupffer cell in the electron microscope. Granules of the reaction product $\rightarrow$ are located in the lysosomes. Magnification $\times 20,500$

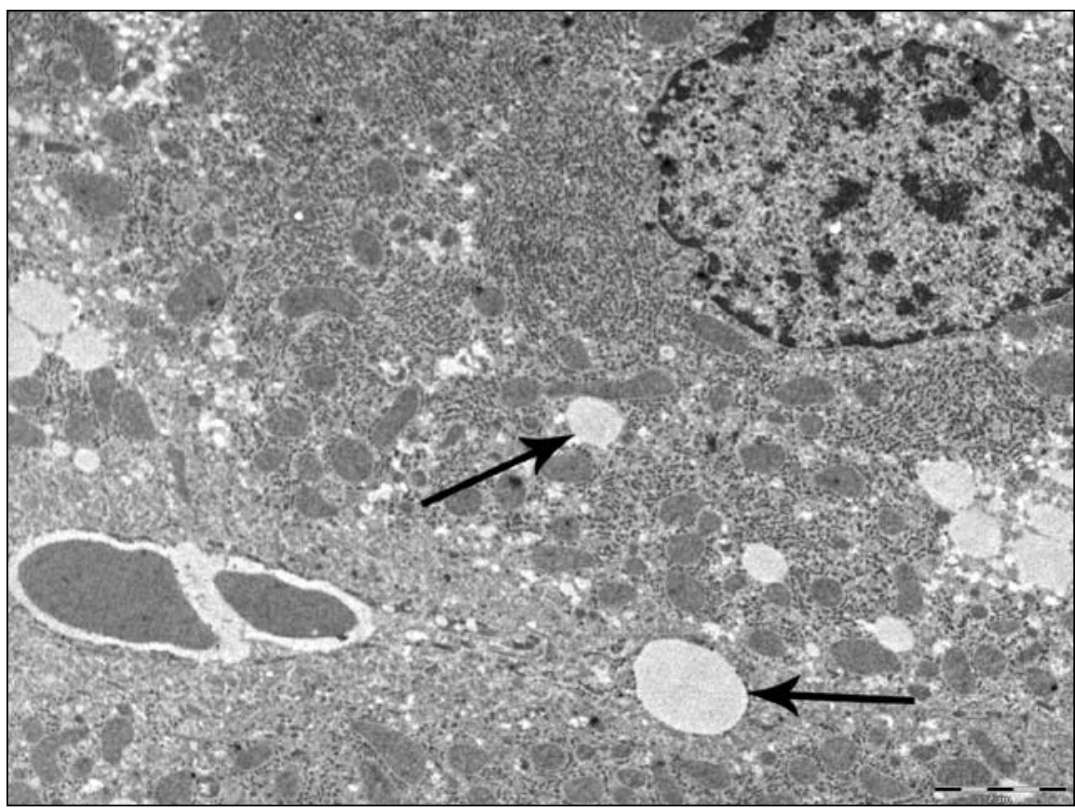

Fig. 6. The electronogram of a hepatocyte demonstrates vacuoles $\rightarrow$ in the cell. Magnification $\times 10,000$ 